\title{
CEYLON: A REVIEW OF THE FIRST YEAR OF THE UNITED FRONT GOVERNMENT IN OFFICE*
}

* Contrary to our general policy, we decided to respect, in this particular case, the author's wish to remain anonymous. - The editors.

It might have been excepted that in a country with a charming weakness for political ceremonial and ritual the first anniversary of the victory of the United Front government ${ }^{1}$ of May/Juni 1970, would have been celebrated with the enthusiasm and in the style befitting such occasions. Massive crowds had thronged the streets of Colombo and independence square on the occasion of the ceremonial opening of the first session of the seventh Parliament in June 1970. The only parallel to the euphoria of those weeks, and the emotional wave of popular enthusiasm seen on that occasion, was 1956 when the present Prime Minister's late husband had won an even more decisive and memorable victory. But in June 1971 the anniversary of victory passed without fanfare and without elation. It would be tempting to attribute this to the traumatic experience of the insurrection which erupted in the first week of April 1971.

But the insurrection, in a sense, was as much a symptom of a malady than a malady in itself. The contrast between June 1970 and June 1971 was the difference between promise and fulfilment.

The U. F. in its election campaigns had given expression and leadership to the inchoate desires and feelings of the people, and their expectations of a better life. After its victory the government declared that it looked upon the results of the general elections as a decisive and overwhelming endorsement of its election manifesto, a document which held out the distinct assurance of purposeful, systematic and fundamental changes in every sphere of life. The throne speech read out at the opening of the first session of Parliament in June 1970 was no more and no less - than a restatement of the election manifesto of the U.F. And one of the striking features of the debate on the Throne Speech (21-24 June 1970) was the fact that the main opposition party, the United National Party, did not move any amendment to the throne speech but expressed instead its general support of the principles embodied in it. The government took pride in the fact that they had spent their years in the wilderness profitably in the systematic study of the problems that faced the country, and in the preparation of working papers on the solutions to these problems. Nothing of the sort had ever before been done by opposition parties in Ceylon.

In these circumstances the very size of the government's parliamentary majority proved to be an embarrassment of riches for it created and sustained an illusion that nothing was impossible if the government only had the will to attempt it.

A visitor to the island at the beginning of 1971 would have carried away the impression that the government was firmly in the saddle and that its leaders were supremely confident of their control of affairs. This impression would have been strengthened if the visitor had chanced to speak to government backbenchers or viewed the spate of legislation that was either being introduced in the House of Representatives or discussed in Parliamentary circles and the press. In the first

1 The United Front consisting of the Sri Lanka Freedom Party (SLFP), the Trotskyist Lanka Sama Samaja Party (LSSP) and the pro Moscow Communist Party (CP). 
three months of 1971 one saw the introduction and passage through the House of Representatives of several items of legislation designed to enlarge the sphere of the state in economic activity or to strengthen the state vis-a-vis private industrial and agricultural ventures. The lop-sided majorities secured by these bills in the House of Representatives were perhaps inevitable in the context of the government's overwhelming majorities but the most striking feature of these developments was the fact that the opposition itself either supported the principles behind this legislation, or put up a very half-hearted show of resistance. It was as though they themselves confessed the impossibility of resisting the relentless flow of legislation designed to give effect to the government's broadly socialist but mainly anticapitalist pattern of thinking.

In March 1971 things began to change. It is not that the opposition was any the less disunited, but they were no longer so very demoralised. The government itself had clearly lost the air of confidence which it had displayed earlier in the year. The twin problems of unemployment and rising living costs (apart from shortages of essential food items) took priority over purely political issues. The government was now confronted by precisely the combination of problems that had brought down its predecessor - rising prices, scarcities of essential food items, and unemployment. And with regard to these it was floundering as badly as its predecessor. The point to be emphasised was that this had happened before the insurrection had erupted.

I.

Perhaps the most constructive achievement of the government in its first year of office were the steps taken to draft a new constitution for the country. One of the first tasks faced by governments of newly independent countries was to depart from an inherited system of government and to develop a political style appropriate to the conditions of their own societies. But Ceylon after over twenty years of independence still retained intact the system it had inherited. And Ceylon's constitution approached the Westminster model nearer than most other Commonwealth Constitutions. The desire to develop a new constitution had wide support not confined to the parties in the government. In a perceptive analysis of the problem a British student of recent constitutional changes in the Commonwealth remarks that: "The present constitutional situation in Ceylon is that of a complex political culture being served by an adventitious constitution which is incapable of making a positive, creative contribution to political life ... The maturity of Ceylon politics makes one doubt that constitutional breakdown is imminent but it seems inevitable that some kind of constitutional innovation (most likely is a new "autochthonous" constitution) will be necessary in the early 1970's2." These comments were made long before the general elections of 1970.

Leftist groups in Ceylon had always regarded the Soulbury Constitution granted to Ceylon in 1947 as an imperialist constitution imposed on the country. The facts however were to the contrary but the accusation persisted, and both the Trotskyist Lanka Sama Samaja Party and the Communist Party consistently sought the establishment of a Constituent Assembly - as in India - to draft a new constitution for Ceylon. But after a while they came to reconcile themselves to a revision of the existing constitution in order to remove what they regarded were some

2 Wolf-Philips, L. 'Post-independence Constitutional changes in the Commonwealth'. Political Studies, XVIII (1970) I, pp. 18-43, see especially p. 35. 
of its objectional features. The Sri Lanka Freedom Party under its founder S.W.R.D. Bandaranaike adopted much the same attitude. During his premiership, a Parliamentary Select Committee prepared the bases of a new constitutional structure. The political instability of the last phase of his term of office as Prime Minister, however, prevented its adoption as the country's new constitution. The SLFP election manifesto of 1960 had stated that these amendments would include: "a reconsideration of the position of the Senate, the definition of democratic and economic rights, and the establishment of a democratic republic ..." Its manifesto for the election 1965 - which had the endorsement of the LSSP and CP - reiterated the theme of a republic, and a revision of the constitution "to suit the needs of the country".

But during their year in the opposition, between 1965 and 1970, the constituent parties of the present coalition, in a far-reaching reappraisal of their stand on this problem, came to the conclusion that a mere revision of the existing constitution was inadequate. They committed themselves to the formation of a Constituent Assembly which would derive its "authority from the people of Sri Lanka and not from the power and authority assumed and exercised by the British Crown and Parliament in establishing the present Constitution of Ceylon nor from the Constitution they gave us".

The policy of the United National Party, in government and opposition, had been to attempt a revision of the Soulbury Constitution; in particular, it advocated that Ceylon should become a Republic with in the Commonwealth. But when in power during 1965 and 1970 it lacked the required parliamentary majority (two thirds of all members of the House of Representatives) necessary to enact legislation for that purpose.

When the Prime Minister, Mrs. Sirimavo Bandaranaike, addressed a communication to the 157 Members of the House of Representatives on 13 July 1970 convening a Constituent Assembly that would be responsible for drafting a new constitution for Ceylon, the first step was taken in severing the constitutional links between Ceylon and the British Crown and Parliament. On this occasion the Prime Minister underlined the fact that this body was being called into existence strictly on the basis of the political mandate received from the people. At the general elections of 1970 the United Left Front parties had sought a mandate “. . . to permit the Members of Parliament you elect to function simultaneously as a Constituent Assembly to draft, adopt and operate a new Constitution which would declare Ceylon to be a free, sovereign and independent Republic pledged to realise the objectives of a Socialist democracy". The Constitution would at the same time secure fundamental rights and freedoms to all citizens. The government regarded its overwhelming election victory as an endorsement of its manifesto, and in particular of the mandate it sought to draft a new Constitution. From the outset the Government emphasised two points about the Constituent Assembly:

1. the Prime Minister's authority to convene a Constituent Assembly and that Assembly's authority to draft a new constitution were both derived from the people;

2. the Assembly's task was not the amendment or revision of the existing constitution but the drafting of an entirely new and autochthonous constitution. 
This procedure for constitution-making was bound to provoke controversy. The opposition parties, the United National Party and the Federal Party at first expressed doubts about its legality but these doubts were resolved and both parties eventually accepted the invitation to participate in the work of the Constituent Assembly. In this deciding to participate in this endeavour they helped to give the appearance of a national consensus on constitutional reform. At the same time, it would appear that they had permitted themselves to be outmanoeuvred in the sense that decisions in the Constituent Assembly would be governed by the overwhelming majority held by the coalition partners.

On 19 July 1970 members of Parliament met as a Constituent Assembly in Colombo outside the precincts of Parliament House. The Governor-General was absent since he was the Queen's Official representative in Ceylon under the constitution bequeathed to Ceylon by the British Government. By meeting outside the precincts of Parliament House they were demonstrating the fact that it was not a meeting of the House of Representatives, but rather a meeting as representatives of the people.

The objective of the new Constitution, the Prime Minister declared, was to set the seal on the freedom, sovereignity and independence of the island. It must be adequate for a two-fold task: in a multi-religious and multi-racial country, it must serve build a nation "even more conscious of its one-ness amidst diversity"; in a nation still engaged in the struggle to complete its independence it must enable the country to advance to the goal of a socialist democracy. In a broadcast on 10 September 1970 Dr. Colvin R. de Silva, the Minister for Constitutional Affairs, set out what the government regarded as the defects of the existing constitution: the existence of an entrenched clause (Clause 29) which safeguarded minorities against discriminatory legislation; the right of judicial review by the courts over the constitutionality of legislation passed by parliament; colonialoriented administration machinery; a bicameral legislature; and the inequality of the adult vote under the existing system of delimitation with its weighted bias in favour of the rural areas and the remoter parts of the country.

The government originally intended to have the new constitution adopted by the end of 1970. But the processes of constitution-making are nothing if not slow and deliberate. After several months of preparatory work the Constituent Assembly met on 16 March 1971 to discuss the first of the Basic Resolutions on a new Constitution. These basic resolutions had been first discussed by a Steering and Subjects Committee consisting of political leaders and constitutional experts. The outbreak of the insurrection in April interrupted the work of the Constituent Assembly. But significantly enough it reassembled in the second week of May almost as soon as the government had re-established its control over the districts which were centres of insurrectionary activity. Indeed the Constituent Assembly was, at this point of time, the most significant, if not the only, form of formal political activity permitted. The government came in for considerable criticism for this decision. The curfew, emergency legislation and censorship on, there was legitimate fear that the free exchange of ideas and organisation of public opinion on constitutional reform would be greatly impeded. To underscore their dissatisfaction with the government's decision to continue with the debate of the Constituent Assembly against the background of a formidable insurrection, the UNP members staged a well-publicised walk-out from the Constituent Assembly at its first meeting in May, but they returned to participate in debates of the Assembly 
within a day or two. The government reassured its critics on this point by guaranteeing that existing restrictions would not apply to discussions and meetings on the constitution. The government adopted the view that a new constitutional structure took very high priority in its plans for political and economic reconstruction in the country. The completion of the drafting of a new and autochthonous constitution, it argued, was a matter of the utmost urgency. Therefore, the debate on the basic resolutions which was resumed in early May came to a conclusion in early July.

The main features of the new constitutional structure as they emerged from the basic resolutions are: a unicameral republican constitution, ensuring the supremacy of Parliament; there will be no judicial review of legislation; a constitutional commission appointed by the national assembly would be the final authority on the constitutionality of legislation; and the independence of the judiciary would be ensured. The original basic resolutions on this question had come in for sharp criticism not merely from the opposition but also from influential groups within the SLFP. The Minister for Constitutional Affairs then amended his basic resolutions on the judiciary to meet these criticisms. The basic resolutions also contained a guarantee of individual rights. It was resolved that the first National Assembly under the new constitution would have a term of six years. Since the present Constituent Assembly would be the first National Assembly, and since the Constituent Assembly was in fact the House of Representatives, it meant in effect that the House elected in May 1970 would have its life span of five years extended by anything up to three more years. This, the opposition urged, was a breach of faith with the people who were given no indication in the government's election campaign that the House elected in 1970 would have a longer life span than the normal five years.

It will be clear that the new constitutional structure would eliminate nearly all the defects of the Soulbury Constitution which the Minister for Constitutional Affairs had delineated on 10 September 1970. Significantly, however, the previously existing system of delimiting constituencies has passed into the new constitutional structure. Its survival reflects the realities of power politics in Ceylon. Originally designed to swamp the radical urban vote, the system of delimination has come to form the basis of the SLFP's hold on power: the rural constituencies. The urban areas have become, by and large, more conservative in outlook, while the rural constituencies have, correspondingly, become less so. To the extent that the SLFP is a left-oft-centre party the present system of delimitation strengthens rather than impedes the process of radicalisation. With the debate on the basic resolutions over, the process of constitution drafting begins. The government believed that the new constitution would be adopted and operative by October 1971.

The revision of the constitution has been accompanied by attempts to re-structure the bureaucracy. The U.F. government's first year of office has been notable for a politicisation of the civil service, both at the level of the higher bureaucracy and the lower ranks. The politicisation of appointments in the more sensitive and influential positions in the higher bureaucracy stems from the government's belief that committed men at the top are essential for the purposeful implementation of socialist policies. This process of politicisation has been accompanied by the establishment of institutional checks on the bureaucracy at a popular level, both within the bureaucracy and outside it. Within the bureaucracy measures have 
been taken to establish and ensure direct and greater participation of the workers in management and administration, through Worker's Councils and Advisory Committees. Outside the bureaucracy the instruments of popular check on bureaucratic government are the People's Committees, and the device of divisional development councils. People's Committees were one of the more controversial proposals of the U.F. during the last election campaign, with the UNP and its allies claiming that these committees would form the basis of a totalitarian political structure. In the form in which they have now emerged they are largely advisory and consultative councils without any direct administrative or judicial functions. The Committees are expected to agitate for and draw attention to local needs and to suggest remedial measures, and to make representations to the bureaucracy on behalf of individuals and groups of individuals. The divisional development councils are intended to serve as consultative and advisory bodies in the co-ordination of the government's plans for economic development at the local level.

The picture that emerges is one of suspicion of the bureaucratic machinery, understandable in the context of the SLFP's "populist" outlook and the LSSP's long-standing ideological distaste for "bureaucratic" socialism on the Stalinist model. There is a deep-seated anxiety to learn from the experience of the socialist states of Eastern Europe where a burgeoning bureaucracy has been an almost logical concomitant of socialisation. But there is nothing in the recent history of Ceylon to encourage the belief that she will be an exception to the general rule that socialism breeds bureaucracy, and that the bureaucracy operating on a momentum of its own eventually establishes itself as an obstacle both to efficiency and social justice. There is the danger that these "popular" councils and committees will eventually find a niche in an expanding bureaucratic machinery and far from serving as a check on the bureaucracy will contribute to its expansion and alienation from the people. Conversely, they could also have a debilitating effect on administrative efficiency, of overenthusiastic and politically influential amateurs are permitted to interfere with the smooth working of institutions, and undermine the morale of the higher bureaucracy.

In the processes of constitutional reform and administrative reconstruction the government had demonstrated political skills of a very high order. And it would seem as though fresh minds and unconventional outlooks have been more effective in posing solutions to such problems than the more conventional wisdom of its predecessors. Not all aspects of government activity are amenable to such an approach, though foreign policy probably is. In contrast to the major powers, small countries like Ceylon can afford the luxury of dramatic innovations in foreign policy. In this sphere, as in most others, the new government began with a flourish by granting full recognition to North Korea, East Germany and the Provisional Government of the National Liberation Front of South Vietnam. The new watchword in foreign policy appeared to be Neutralism with a leftward tilt. These well-publicised re-appraisals appeard to be exuberant gestures of defiance directed at some of the major powers of the west, the United States and West Germany. Ceylon broke off diplomatic relations with Israel to underline its commitment to the Arab cause. Ceylon is too small for her foreign policy decisions to have anything more than a minimal and marginal effect on the balance of forces 
in the world. But these gestures were important psychologically and were devised as much for home consumption as for any real impact they would have outside. There was more than a streak of naive sentimentalism about these foreign policy decisions, and not enough hard and sharp bargaining to derive the maximum economic benefit from the recognition that was being conferred on countries which desperately sought it from any source to bolster up their status as sovereign states.

But there were fields of government activity in which existing problems were impervious to solution even by the most imaginative measures. Among those were the crucial questions of economic development and finance. And there the government seemed slow and clumsy in contrast to its innovative daring in other fields including foreign policy. It was precisely in these most sensitive fields that the very size of the governments parliamentary majority proved to be an embarrassment, for the illusion persisted that nothing was impossible if the government only had the will to attempt it. A really formidable balance of payments crisis which it had inherited restricted the government's manoeuverability. Because the government in its election campaign had held out the prospect and promise of effective and swift solutions to the social and economic problems which confronted the people, problems which by their very nature did not lend themselves to quick and dramatic solution, it laid itself open to criticism when the quick solutions did not emerge.

Ceylon's economic profile is paradoxical. More than half its national budget is earmarked for expenditure on three social services: education, health and food subsidies (the government's decision based on one of its most effective election slogans - to restore the rice ration to two measures per person per week increased the bill on food subsidies by as much as Rs. 377 million). But this is perched on a foundation where the annual rise in the Gross National Product per head (taking into account the growth in population) was marginal at best. The Gross National Product at constant prices rose by $4.1 \%$ in 1970 as against $5.1 \%$ in 1969. Allowing for a population increase of $2.1 \%$ in 1970 the GNP per capita rose by only $2 \%$. At the same time prices increased by $5.9 \%$ in 1970 which though lower than in 1969 corresponded to the increase in 1968. The economic stagnation which these figures indicate has classically inevitable consequences: unemployment, a rising cost of living, budgetary difficulties and a balance of payments problem. Ceylon's foreign trade in the post-war period has had only two short-lived booms - the Korean war boom of 1951-52 when rubber prices shot up sharply, and the tea boom of 1954-56. During this period external assets shot up, but thereafter they have continued to decline steadily up to the present time. Since 1957, with the exception of 1965 Ceylon's current payments to the rest of the world have exceeded her current receipts. The crux of the problem lies in the fact that tea prices - Ceylon's main source of foreign exchange - have continued to fall. Between 1947 and 1970 the quantity of tea exported has increased by over $60 \%$, but the increase in foreign exchange earnings has been a mere $10 \%$. Ceylon's two other traditional sources of foreign exchange, rubber and coconut have not fared much better. Since 1961 the terms of trade have steadily worsened. Between 1962 and 1964 the index of the terms of trade (base $1947-100 \%$ ) fell from 142 to 105 : a decline of $26 \%$. Then again between 1965 and 1969 the index fell from 112 to 88 , a decrease of over $21 \%$. In 1970 alone the terms of trade deteriorated by $3.6 \%$. 
The Central Bank of Ceylon in its Annual Report for 1970 (page 20) summarised the situation as follows, emphasising the stark picture of economic stagnation, and the very limited nature of the options available to the government in posing solutions to the problem:

"The fundamental imbalance in Ceylon's balance of payments is basically
the result of expenditure outstripping available resources. A solution to this
problem is easier stated than implemented. The basic solution is to spend
less or, which is the same thing, to save more. Ceylon's current rates of
saving are inadequate to maintain a development programme capable of
absorbing the available work force. In seeking a solution to this problem,
excessive expenditure would have to be curtailed. Such curtailment must fall
on current consumption and not on investment, for a higher rate of invest-
ment is not only the right solution to the unemployment problem but the
goods and services which a higher rate of investment would eventually
generate would form a lasting solution to the other problems of the day such
as the high cost of living and the disequilibrium in the balance of payments.
.. [There are] no quick solutions to the balance of payments problem
confronting the country. Since each of the avenues available has its own
problems and limitations action will need to be taken on several fronts at the
same time. A concerted national effort maintained over a fairly long period
will be necessary if the balance of payments is to be placed on a sound
footing."

Partly because the problems have been created by external economic forces totally beyond its own control government's response has not measured up to the magnitude of the problem. Firstly, its budgetary policy has been basically redistributive in intent and impact, with increases in taxation at the higher levels, compulsory savings, and an effective ceiling on incomes. This policy is a reflection of its belief that an increase in GNP was not an end in itself, that imperatives of social justice were just as valid in the assessment of progress as crude economic growth. Secondly there was its faith in nationalisation and the public sector in its strategy for economic development. The corollary to this was the down-grading of private enterprise. Thus the government declared that the import trade in all essential services would be handled by the state while its share of the export trade would be progressively increased; and the central wholesale internal trade in all essential commodities would be controlled by the state. The government believes that these measures would facilitate planned economic development and at the same time guarantee the equitable distribution of essential items of consumption. A State Trading Corporation was set up to co-ordinate and rationalise importexport ventures of the government.

This strategy could be criticised on several counts. Firstly, redistribution of income in a basically poor country could be self-defeating in terms of economic growth, whatever the social justice of the measure might be. Not only is the "redistributable surplus" small in terms of the economic needs of the country, but such redistribution could cause dislocations in employment and the earning capacity of large sections of the poor. The second criticism emerges from this: All the government's efforts so far amount to no more than a mere slicing of an economic cake of a limited size; little has been done with a view to increasing the size of the cake by economic development. Thirdly the government's economic strategy is vitiated by its own tactics. On the one hand it is as much committed to a mixed economy as its predecessor, even if the ratio of the various ingredients varies. The emphasis on public sector ventures stems more from ideological commitment 
than a dispassionate assessment of optimum economic benefits. For it is a fact that the return on the investment in the State's manufacturing, trading and service ventures is as low as $1 \%$, an index of the maladministration and gross inefficiency which characterise the management of most of them. Dispite its ideological distaste for the private sector the government concedes the need to permit its survival. Indeed it even concedes the need to divert its talents and skills more efficiently to the expansion of its sales of non-traditional exports. At the same time government legislation such as the Business Undertakings (Acquisition) Bill which would permit the expeditious takeover by the state of any business empolying more than 100 persons adversely affects the morale and confidence of the private trade. Thus the government's economic policies are contradictory and self-defeating. The government has made much of its rejection of the conventional wisdom of the 'right' in economic development. Its critics can reply that the substitute for it is nothing more than the conventional wisdom of the "left" and that this latter calcified by ideological commitment is not likely to have any greater impact on the basic problem of accelerating development in a stagnant economy.

It was the emergence of these economic problems in their most politically embarrassing form by the beginning of January 1971 that made it difficult for the government to sustain the air of confidence that it had once exuded. At the beginning of 1971 the people at large were faced with an acute shortage of chillies, an item absolutely essential in the making of curries. This was a normal seasonal shortage, but prices shot up to anything between six to eight times the official controlled price at which the government sold it on the ration. By March the price of chillies had stabilised at something just above the controlled price. In its place there were shortages of other items, chiefly sugar, salt and garlic. All these items with the exception of salt which is produced in sufficient quantities within the country are largely imported. Local production is too small to have anything other than the most marginal effect on prices.

The Ceylon consumer has been and is still being fed largely on imported food items bought with foreign exchange at a time when the state's reserve of foreign exchange is abysmally low. The shortage of foreign exchange makes it impossible to build up adequate buffer stocks of food items and the country has a precarious ship-to-mouth existence. Buffer stocks of rice, flour and sugar are seldom adequate for more than six weeks' consumption. As regards foreign exchange the situation is even more precarious. The Central Bank seldom has liquid foreign assets sufficient to finance more than a week's imports. This could, during an especially affluent period, stretch to cover a fortnight's imports, but it is never more than that. Locally, these shortages develop a logic and momentum of their own. Lack of confidence in the regularity of stocks causes panic-buying by all those above the poverty line and this aggravates the situation further. The government has attempted to meet this by prohibiting (under emergency regulations) the stockpiling of anything more than a "normal" fortnight's quota of these items in homes. But the definition of "normal" is necessarily vague, and in any case it is almost impossible to make meaningful attempts to enforce such regulations.

These problems are especially embarrassing to the present government for two reasons. The starting-point of the Ceylonese villager and the Ceylonese worker is much higher than the Indian standard, and precisely for this reason their expectations are also so much higher than those of their Indian counterparts. More important - the present government in its election campaign promised the elec- 
torate a plentiful supply of food items and even the abolition of the existing rationing system of "subsidiary" foodstuffs. Instead the imperatives of a tight economic situation have made the rationing system even more rigid, with little prospect of a relaxation in the near future. One final point needs mention: unemployment. At the government's assumption of office the total number of unemployed ranged between 350,000 and 450,000, representing a proportion of between 101/2 \% and $13 \%$ of the labour force. Since data on employment in Ceylon are of questionable accuracy those estimates are necessarily crude. Nevertheless, unemployment poses the most formidable challenge to the government. Its response to this challenge has been more imaginative and dynamic than that of its predecessor. It set forth on a Rs. 200 million crash program on the creation of job opportunities. But even this could merely touch the fringes of the problem. There is the clear realisation that on the solution of this problem of unemployment would depend the future political stability of the country for a large proportion of the unemployed are relatively well educated young people (most of whom come from rural areas) impatient with the pace of reform in the country.

One of the lessons of the general election of 1970 was the increasing radicalisation of the rural areas. Already these areas have produced a class of "populist" politicians who did not share the elitist and essentially liberal outlook of their party leaders. These men pose a fundamental challenge to the established order and sooner or later they will demand their share of power. The educated unemployed from the villages are likely to give leadership to this quest for power, and in doing so generate a force that would tear the country apart. By the middle of March 1971 this challenge and this threat had become a deadly reality. The governments' confrontation with the People's Revolutionary Movement, an ultra-left organisation dominated by unemployed graduates and youth (popularly known as the "Che Guevarists") marks the end of its first phase in office. The insurrection which broke out in April was a stern warning to the political leadership of the UF and a challenge to its credibility as a genuinely socialist government.

III.

There was some poignancy - for the government more than for most others in the fact that the insurrection was Ceylon's version of the international phenomenon of youth unrest, and the Janatha Vimukthi Peramuna (the People's Liberation Front) drew the vast bulk of its support from young people below the age of 25 . There was poignancy too in the fact that the movement was reacting violently because it felt desperately unhappy that a government which it had helped to bring into office had not taken meaningful steps, fast enough, to fulfil the promises held out to them. And the truth is that during the election campaign promises were given of immediate and substantial relief of grievances, and solutions of existing problems. The pace of change and reform in the ten months of the government's tenure of office to the end of March had proved insufficient to satisfy the aspirations of the more militant and articulate young people whose political appetite had only been whetted by the lowering of the voting age to 18 . Having helped to bring the government into power through the ballot they were set on throwing it out with bullets. The political arm of the movement, the JVP, in its support of Mrs. Bandaranaike's coalition had made it plain that sweeping campaign promises of really thoroughgoing socialisation 
would have to be kept if their support was to continue. Warnings on these lines were made regularly after the elections and grew steadily more specific in terms of threatened revolutionary action.

No government can translate its electoral pledges into concrete achievements within a year, and social and economic problems of the magnitude of those facing the present government do not lend themselves to quick and dramatic solution. But the rhetorical flourishes indulged in during an acrimonious election campaign proved to be an embarrassment when economic conditions showed no signs of improvement and the number of unemployed did not decrease.

With the UNP demoralised by a stunning defeat and a bitter leadership struggle and in no mood to capitalise on the government's shortcomings, the JVP emerged to pose a challenge of a totally different sort. During the years of the Senanayake government (1965-70) the JVP had remained a clandestine ultra-left group organised on a cell system. Their potential as a revolutionary movement became clear to the government and the police in the last months of the Senanayake regime and preliminary investigations were conducted into their subversive activities. When the present government came to power, it was not unduly worried about the activities of the JVP, and it would appear that the public meetings held by the group were regarded as being somewhat beneficial since they served as a safety-valve for youth unrest. But even when there was mounting evidence of preparations for violence directed against the state the government was reluctant to use the full force of its authority against the movement. Indeed the government seemed oblivious to the threat from the JVP. Even at the end of March they seemed more concerned about enemies from the "right", and were still reluctant to concede that there could possibly be a threat from the "left". Thus the JVP was left undisturbed in its clandestine activities. Its organisational network spread to all parts of the country, becoming all the while increasingly sophisticated and efficient. It set about making preparations for a violent confrontation with the government. If the government's response to this growing challenge was seemingly lackadaisical, this was understandable in the context of the country's long and enviable record of peaceful politics. Ceylon had had no experience of violence in politics, and the government felt that the JVP was indulging in rhetorical gestures and verbal violence rather than in any serious preparation for subversion.

By about mid-March there was positive evidence of preparations for a violent attack on government institutions. Caches of homemade grenades began to explode in their hiding places killing and injuring some of the insurgents. At this point a state of emergency was declared and the security forces began a systematic search for clandestine arms dumps. The success of the police and military in these activities had the effect of making the insurgents advance their plans for an attack on the government. The attack came on $4 / 5$ April. The rebels relied on secrecy and swiftness of movement for success, in the belief that by surprise alone they could overwhelm the un-alerted armed forces of the state. The government realised that this was the beginning of a full-scale insurrection. Though they had information of a rebel movement they never expected it to be of such a formidable nature. The Prime Minister herself in a broadcast talk to the nation on 24 April admitted that the government was militarily unprepared for the kind of concentrated armed attack that the insurgents launched. ". . . We found", she declared, "that we had inadequate weapons, ammunition and aircraft to meet a 
sustained threat over a long period of time by the terrorist insurgents . . ." But with speedy assistance from a combination of friendly powers - India, Great Britain, the United States, Yugoslavia, Egypt and Pakistan - the armed forces were placed on a more meaningful level of readiness to meet the challenge of the insurgents. Within three weeks they had broken the back of the insurgent movement, and re-occupied all the territory lost to the insurgents.

There was a hard core of insurgents confined to pockets in the jungles and less accessible parts of the country. The mopping-up operations were to take nearly two months. In response to the government's offer of an amnesty between 1 and 4 May, about 6000 insurgents surrendered. Scattered groups of insurgents remained at large and engaged in sporadic acts of violence. Early in June a second amnesty on the Poson week-end (a religious occasion commemorating the advent of Buddhism to Ceylon) was offered. The government emphasised the fact that no amnesty would be granted thereafter. The government's reluctance to order an all-out offensive to flush the insurgents out of their jungle hideouts could be explained thus: no government elected by the people likes the prospect of prolonged conflict which carried with it the prospect of heavy casualties among the young - the insurgents were almost all young people; and there was the even more frightening prospect of inflicting death and destruction on a peaceful civilian population that had given not the slightest support to the insurgents.

The insurrection failed because it had no support from the people. The insurgents presented no serious alternative political programme to the people. Nor did they have the advantage of a dominating foreign presence against which they could have stirred up nationalist sentiment. They were not the spearhead of a popular outburst against a tyrannical or repressive regime. Instead they were opposed by a popularly elected left-of-centre government which had taken office on a massive wave of public support only ten months before the insurrection broke out. The fact that Ceylon had at this point of time a government which enjoyed the support of the organised trade-union movement was of crucial importance, for a regime which did not have such support could not have stood up so firmly to the thrusts of the insurgents. There were a few regions which the insurgents controlled for brief periods in April. And during their "rule" of these areas they demonstrated a shocking immaturity and naiveté. They showed no imagination, no fresh thinking in the administrative structure they devised. Instead their administrative machinery was a grotesque parody of the very system they were pledged to destroy. In the sphere of administrative organisation their outlook was archaic. Finally, these youthful revolutionaries, though they managed to control if not occupy some areas of the island, and compelled government forces to confine their activities to the large towns and main trunk roads, never showed any solid grasp of strategy. They diffused their energies in sporadic attacks spread over many parts of the country, when concentration on a few strategic points might have suited their purposes better. Though some of the cells demonstrated considerable skill in guerrilla tactics, the insurgent movement as a whole broke every rule that experienced guerrilla fighters would have observed. Once the momentum of their original thrust had been absorbed and repelled the leadership showed a lack of resourcefulness in not being able to sustain their attacks though they had the forces for this purpose. 
But though the government has succeeded in defeating the insurgents militarily, the underlying conditions that went to create the insurrection remain. If the insurrrection highlighted the harsh realities of economic backwardness, it also aggravated the economic problem in many ways. There is the damage caused to state and private property and the temporary loss of foreign exchange. Thus scarce economic resources will need to be diverted to reconstruction. And there will be, inevitably, a diversion of resources to the modernisation of the armed forces. Hitherto only a tiny proportion of the budget has been spent on the armed services. The cost or re-equipping and modernising the forces, quite apart from expanding each of the services in turn, will have an appalling effect on the economy.

There is in government circles a recognition of the fact the restoration of law and order, and the more efficient deployment of military strength will be less effective than would be the available of capital to finance development and create jobs in coping with the social and economic problems which form the background to the insurrection. To achieve this in the face of a grave economic crisis is the daunting necessity which confronts the government - to demonstrate the efficiency of a democratic political structure in achieving speedy economic development and the re-distribution of social capital on a more equitable basis. The future not only of the government but also the viability of the democratic system - one of Ceylon's most highly esteemed possessions - will depend on its performance in meeting the challenge of the two most crucial issues it faces inflation and unemployment. 